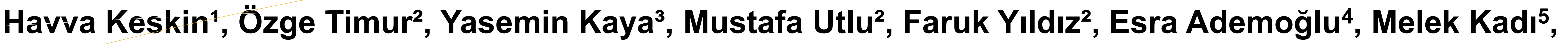
Mehmet Emin Budak ${ }^{2}$, Hakan Gözc ${ }^{2}$, Hakan Sevimli ${ }^{2}$, Şenay Arıkan Durmaz ${ }^{6}$, Ayşe Çarlıoğlu ${ }^{7}$,eynep Kamalak ${ }^{8}$
${ }^{1}$ Medeniyet University, Department of Internal Medicine, İstanbul, TURKEY
${ }^{2}$ Erzurum Regional Training and Research Hospital, Department of Internal Medicine, Erzurum, TURKEY
${ }^{3}$ OrduUniversity Medicine Faculty, Department of Internal Medicine, Bolu, TURKEY
${ }^{4}$ Abant Izzet Baysal University Medicine Faculty, Department of Internal Medicine, Ordu, TURKEY
${ }^{5}$ Erzurum Regional Training and Research Hospital, Department of Dermatology, Erzurum, TURKEY
${ }^{6}$ Kırıkkale University Medicine Faculty, Department of Endocrinology, Kırıkkale, TURKEY
${ }^{7}$ Erzurum Regional Training and Research Hospital, Department of Endocrinology, Erzurum, TURKEY
${ }^{8}$ Buhara Medicine Center, Gynecology and Obstetrics Clinic, Erzurum, TURKEY

AIM:

Polycystic ovary syndrome (PCOS) is the most common endocrine disorder that affects women of reproductive age. Clinical and biochemical characteristics are similar to metabolic syndrome. Insulin resistance in patients with metabolic syndrome, is associated with serum uric acid levels. In our study, we aimed to investigate the relationship between serum uric acid levels and clinical and laboratory in PCOS patients.

\section{MATERIALS AND METHOD:}

172 PCOS patients and 34 age and body mass index (BMI) matched control, a total of 206 cases attending at endocrinology outpatients clinic included in the study. Early follicular phase, blood samples were taken after 12-hour fasting. Basal serum hormone levels were measured by immunoassay.

PCOS tanı kriterleri neler? Şu şu hastalıklar ekarte edildi denmeli, Non klasik KAH mesela? Çok merkezli olduğunu belirtmek gerek

USG yapıldı ise fenotip tam tanımlanmalı. Modifiye ferriman galwey skorları verilmeli Alkol alımı ekarte edilmiş olmalı.

Diyabet ve metabolik sendrom ekarte edilmeli,, çünkü ürik asit çok yükselebilir. PCOS lu hastalardan kaç kişi diyabetikti kaç kişide prediyabet özellikleri vardı belirtilmeli

Korelasyon için ayrı tablo verilebilir.

Yaş ve BMI ort+-SD olarak mutlaka verilmeli

\section{RESULTS:}

Uric acid levels was statistically significantly higher in PCOS than control group $(4.25 \pm 1.07$ PCOS control 3.7 $\pm 0.79, p=$ 0.048) (Figure 1). Uric acid levels were positively correlated with BMI, total cholesterol,, insulin, cycle time, Feriman Gallwey score and negatively correlated with HDL cholesterol levels. Uric acid levels were higher than 2 tibirmes in PCOS group independently age and BMI with multivariate logistic regression. (Table 1)

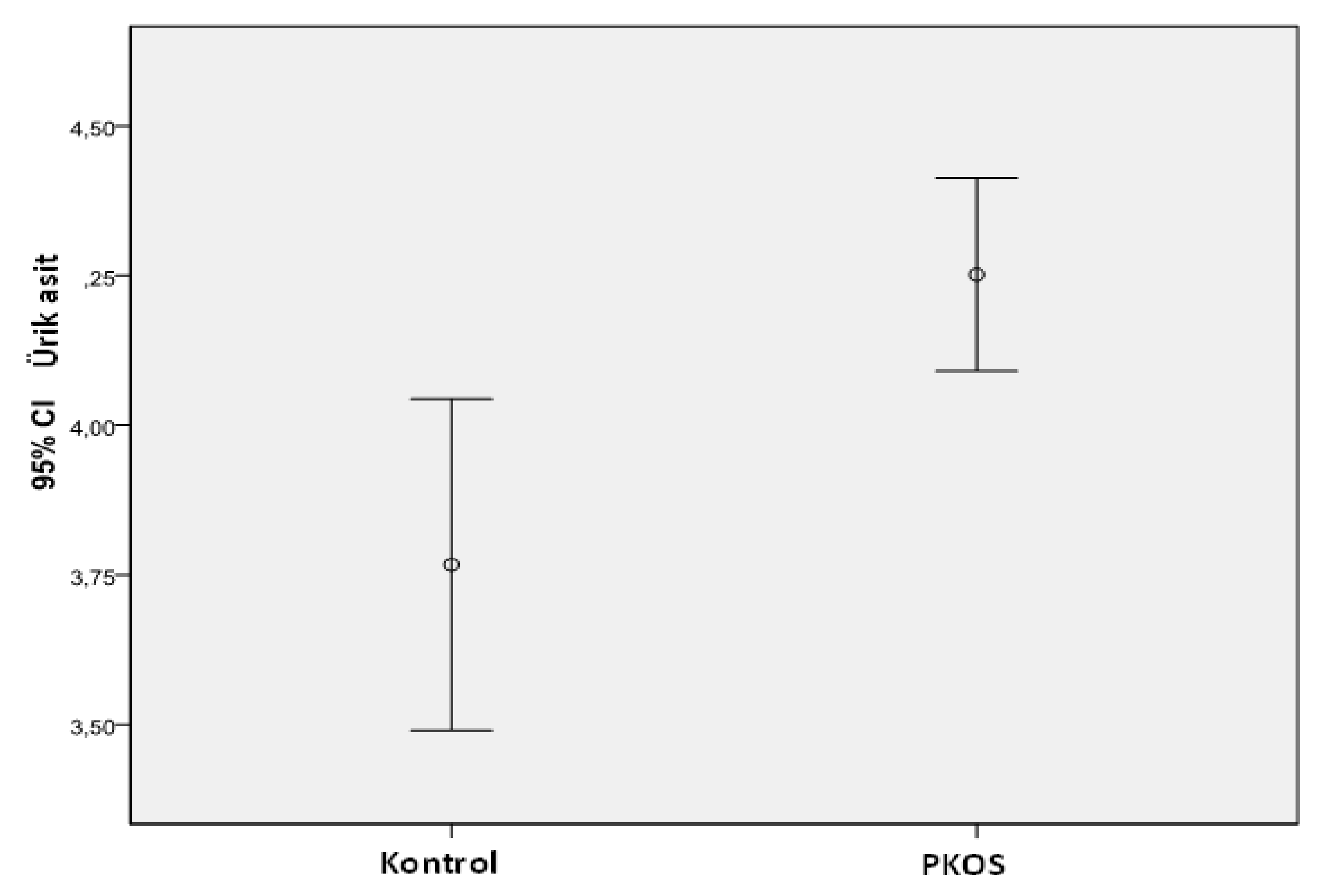

Figure 1: Uric acid levels in PCOS and control group.

\begin{tabular}{lll} 
& \multicolumn{1}{c}{$\beta$} & \multicolumn{1}{c}{$p$} \\
\hline Uric Acid & 0,726 & $0,048^{*}$ \\
Age & $-0,010$ & 0,841 \\
BMI & 0,185 & 0,120
\end{tabular}

$\mathrm{P}<0,05$

Table 1: Uric acid levels are higher in PCOS group independent of other variables.

\section{CONCLUSION:}

Uric acid levels in study group WERE significantly higher independent of age and BMI. Cardiovascular risk factors; LDL, insulin, triglycerides, BMI was positively correlated with uric acid in PCOS group. Clinical indicators; Feriman Gallwey score and cycle time was also positively correlated. Elevated uric acid levels in PCOS patients may be a risk factor for cardiovascular disease, may show negative results in the clinic. 